\title{
An Integrated Contribution Approach Focusing on Technology for Climate Change Mitigation and Promotion of International Technology Cooperation and Transfer
}

\author{
Kanako Tanaka', Ryuji Matsuhashi' ${ }^{2}$, Koichi Yamada ${ }^{2}$ \\ ${ }^{1}$ Center for Low Carbon Society Strategy, Japan Science and Technology Agency, Tokyo, Japan \\ ${ }^{2}$ University of Tokyo, Tokyo, Japan \\ Email: tanaka.kanako@jst-Ics.jp
}

Received 18 April 2016; accepted 17 June 2016; published 20 June 2016

Copyright (C) 2016 by authors and Scientific Research Publishing Inc.

This work is licensed under the Creative Commons Attribution International License (CC BY).

http://creativecommons.org/licenses/by/4.0/

(c) (i) Open Access

\begin{abstract}
Various technologies exist for climate change mitigation. Technology transfer is important for the efficient use of these technologies globally. Such transfer/cooperation should be implemented, at sector basis, broadly and unlimitedly beyond conventional framework. In this paper, an Integrated Contribution Approach is proposed as a domestic as well as a global strategy. This approach unifies two approaches: seeking ways to reduce greenhouse gas (GHG) emissions, further improve technical capabilities and encourage technical innovation; and implementing technology transfer effectively, clarifying contributions and promoting efforts to achieve substantial global GHG reduction. As an illustration, this paper estimated the technical potential of solar generation in the developing world by the year 2020, considering current and anticipated technology development. The estimate suggests a huge possibility for $\mathrm{CO}_{2}$ reduction as well as business opportunities through worldwide technology cooperation based on recognition of the importance of continual technology development. To achieve such goals, a scheme promoting incentives for private investment is indispensable as it is essential to use economic forces as well as government policy. This paper describes the following considerations: establishing a simple, easy-to-access scheme that can concentrate private resources on technology transfer; clarifying reduction efforts through measuring, reporting, and verification (MRV); applying it to conditionality together with financial and/or economic internal rate of return (FIRR, EIRR); and establishing a database and analysing data on the technical contributions and dissemination of projects.
\end{abstract}

\section{Keywords}

Technology Transfer, Integrated Contribution Approach, Energy Efficiency, Climate Change Mitigation, MRV 


\section{Introduction}

\subsection{Background}

According to the April 2014 report of the Intergovernmental Panel on Climate Change [1], we need to reduce the amount of greenhouse gas (GHG) emissions in the world by $40 \%-70 \%$ from 2010 levels by 2050, and then almost zero or negative by 2100 , to limit global temperature rises below $2^{\circ} \mathrm{C}$ during the 21 st century. The international framework for pursuing GHG reduction, beyond the Kyoto Protocol, has been examined at the United Nations Framework Convention on Climate Change (UNFCCC).

The first commitment period of the Kyoto Protocol from 2008 through 2012 was expired, and discussions regarding the next framework began at the Ad Hoc Working Group on the Durban Platform for Enhanced Action (ADP). The main points of the next framework were clarified at the 20th session of the Conference of the Parties to the UNFCCC (COP20) in 2014. At the second session of the ADP (ADP 2) in May 2013, in the context of a discussion of the next framework and prerequisites to enhance action on climate change mitigation, broad consensus was reached on the following points [2] [3]:

- All countries (parties) must participate.

- The framework should be based on common but differentiated responsibilities (CBDR) and principles of equity.

- Efforts and commitments should be determined nationally, depending on the circumstances of each country.

- Common rules to govern measuring, reporting and verification (MRV), as well as performance review, should exist to ensure the transparency and environmental integrity of all countries' actions.

COP19 held in Warsaw, Poland in 2013, decided to invite "all parties to initiate or intensify domestic preparations for their intended nationally determined contributions [...] and to communicate them well in advance of the COP21" [4]. Finally, at the COP21, the Paris Agreement was adopted, which was the significant first step to the world's addressing climate change issues concertedly for long-term target such as limiting the temperature increase to 1.5 Celsius degree above pre-industrial levels [5].

The international situation concerning global warming has changed greatly since the signing of the Kyoto Protocol. A shale gas revolution has occurred in the United States, making it easier to switch from coal to gas and enabling GHG reduction to progress more economically. Development of shale gas resources is attracting attention in China too; in addition, China has developed and may implement carbon capture and storage (CCS) capacity. In Europe, a new financial market was expanded with an emission trading scheme, even though a review found that the "short-run environmental effect has been limited as a result of loose caps or caps that have not proved to be constraining" [6].

In the current situation, Intended Nationally Determined Contributions (INDCs) which were submitted for COP21 from many countries contained numerical targets. On the other hand, the effectiveness of setting numerical targets for the entire country by political means has been regarded as questionable. In the past Kyoto framework, countries committed only to overall numbers without reference to the specific situations of each country, so the targets were not accompanied by concrete visions of technology development and deployment, either within each country or globally. Many regimes proposed thus far have had similar downsides even though they aimed at securing considerable amounts of global emission reductions, for example, through full participation using global cap such as contraction and convergence approach [7], common but differentiated convergence approach [8] and multi-stage regime [9]. In this context, researchers have proposed approaches that would enable us to allocate the $\mathrm{CO}_{2}$ reduction burden equitably to each country based on a sectoral perspective. These approaches include for example an improved triptych approach [10] [11] and a multi-sector convergence approach [12]. The target-setting methodologies through these approaches have suggested country-level targets under the assumption that each country should have a homogenous framework for $\mathrm{CO}_{2}$ reduction; this assumption has not permitted a large divergence in targets or flexibility in the actions to be taken. Moreover, there have been debates about the concept of a sectoral-based approach, which has various meanings and methods of application [13]-[15] (see also the appendix to this paper). A sectoral approach to framework design has been considered as a promising way to advance climate mitigation because it can directly address reduction steps by actual players in society and promote public-private partnerships, even though some activities related to the sectoral approach may be implemented outside the UNFCCC. Currently ongoing international sectoral initiatives, such as the International Partnership for Energy Efficiency Cooperation (IPEEC), focus more on energy efficiency and are not directly related to climate change. A concrete framework based on a sectoral approach to 
climate mitigation is necessary, and it should be applicable to the real world and effectively linked with national-level actions.

Past experience and analysis shows that reliance on top-down establishment of numerical targets will not be adequate for pursuing actual low carbon economy. However, each country is still required to have certain clarified goals with regard to its contributions toward climate change mitigation. In addition, Kyoto mechanisms, such as the Clean Development Mechanism (CDM), need those targets for their operation. CDM has encouraged GHG mitigation projects, but the validation time period was too long and "additionality" issues posed a further barrier to widespread implementation.

This paper proposes a scheme that could solve problems resulting from the reliance on numerical target setting and limited use of crediting mechanisms. In addition, it suggests ways to stimulate technology research and development (R \& D) with sensitivity to each country's situation and to advance global climate mitigation through private-sector participation.

\subsection{Requirements for the Next Framework}

In the debate on the future framework concerning climate change mitigation, the following four components are considered essential:

- A fair, effective structure that will lead to substantial global GHG reduction.

- A mechanism for promoting private investment incentives and utilizing various business opportunities in the economic development of developing countries.

- A strategy that can be applied both domestically and internationally, especially with regard to technology transfer, for improving and evaluating sectoral energy efficiency as well as assessing the intensity of GHG emissions.

- A mechanism of strengthening domestic policies and measures to address issues of sustainable development and other global concerns.

The central concern, indeed, is to consider the ways to mitigate global warming. Precisely, the place and the ways of reducing GHG must be flexible, and any effective method can be adopted if applicable. However, the interests of each country in international negotiations are often complicated with the result that this major premise has often been downplayed. It is desirable that GHG reduction be advanced globally and in an efficient manner. It is very important to pursue a sustainable society from a global perspective so that, in both economic and environmental discussions, our shared global interests are highlighted and technical development is promoted. Moreover, not only country-level initiatives but mechanisms to make the most of private-sector resources to achieve global change are required.

\subsection{Objectives}

Considering the above four points, this paper proposes and examines the Integrated Contribution Approach scheme that is designed to unify climate change mitigation efforts within and beyond individual countries. The scheme contains a framework for the promotion of overseas technology cooperation and transfer, aiming towards achieving both world economic growth and successful actions to avert global warming.

\section{Application of the Integrated Contribution Approach Based on Technology Capabilities for National and International Climate Strategy}

The technologies contributing toward reduced carbon emissions vary considerably and include, for example, renewable energy, energy savings, $\mathrm{CO}_{2}$ storage, fuel switching, and non- $\mathrm{CO}_{2}$ emission control technology. These approaches have been broadly developed and deployed through technical and institutional efforts. In particular, energy efficiency is broadly recognized as a low or negative-cost technical measure applicable to many sectors of the economy [16]. The enforcement of energy-saving policies across the globe during the past 20 years is astonishing. The number of policies related to energy efficiency in International Energy Agency (IEA) member countries and BRICS countries (i.e. Brazil, Russia, India, China, and South Africa) has rapidly increased by more than 10 times in 20 years from 1990, approximately 3.5 times from 2000 in 10 years [17]. In all countries, the maintenance and further improvement of the level of available technology are important for encouraging and developing industry. Moreover, most of those techniques have high GHG reduction effects in countries beyond the one in which they are initially applied, particularly in developing countries. Promotion of technology coop- 
eration and transfer contributes to GHG emission reduction globally. Many effects of technology transfer for climate mitigation had been already well-discussed [18] [19]. Issue papers and review articles of good national practices, case studies discussing various problems and barrier/opportunities have been published [20]-[25]. However, most assessments of technology transfer for climate mitigation thus far have mainly focused on the benefit of host country regarding the contribution toward climate mitigation and economic development. Although past assessments partially emphasized some effects such as that mentioned by Kypreos and Turton [26] regarding the effect on the industrialized country, few have focused on the benefits to the industrialized countries. In reality, such international cooperation can activate domestic economies by offering the potential for market expansion through overseas deployment. As the benefits of donors, credit issuing by crediting mechanism such by CDM and JI is cited in the past assessments, but other advantages have not been significantly argued. The approach proposed in this paper included the point that would become the incentive to the technology transfer for the donor country having something beyond a stereotype concept. Moreover, it showed a way of thinking which is being utilized for an international framework by evaluating them quantitatively from now on.

In the UNFCCC discussion, it was widely stated that the mitigation framework should be based on efforts assigned to each country according to its own situation, which was well appeared in the process to the Paris Agreement. On the other hand, it has been common practice globally to advocate for concrete, often numerical targets - which may or may not be legally binding — and it is necessary to make efforts to achieve these targets. In contrast, the national and international framework for climate change mitigation proposed in this paper is shown in Figure 1. Its process for setting and achieving domestic targets focuses on technical development, diffusion and deployment.

The basis of existing proposals and analysis about future regime and/or target setting for climate mitigation so far were well-approaching to "global GHG reduction for lower atmospheric concentration level" [7]-[12], [27] [29]. Integrated Contribution Approach is, however, the one pursuing "technology development and diffusion/penetration" and "global level construction of low carbon society". It does not primarily aim at securing global reduction but proposes the scheme at which each country does its effort for reduction by effective way from specialty area, resulting in the promotion of global reduction.

The approach proposed in this paper comprises the following four pillars (see Figure 2).

1. Improving the level of domestic sectoral level of technology for climate mitigation and for saving energy (Technology R \& D),

2. Promoting technology transfer and cooperation by applying superior technology regarding cleanness and efficiency to host country (Technology diffusion),

3. Positioning as domestic climate mitigation goal by combining these two (1 and 2) targets (Target setting),

4. Constructing technological, economic and social infrastructure for project promotion (Surrounding environment for project promotion).

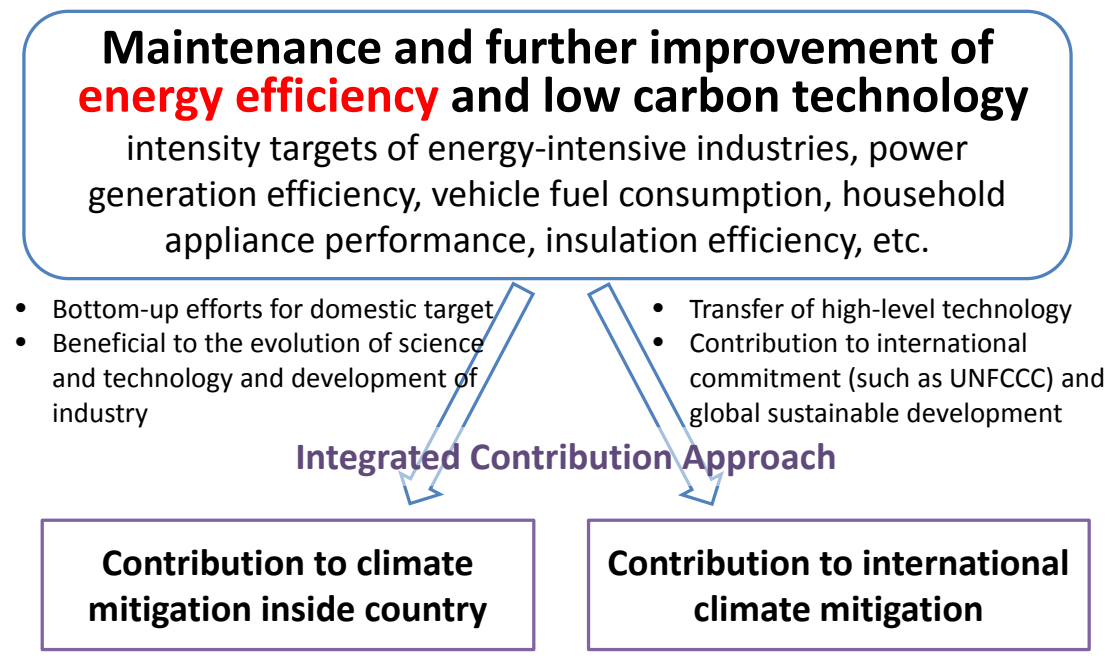

Figure 1. Proposed national and international framework scheme on climate change mitigation. 


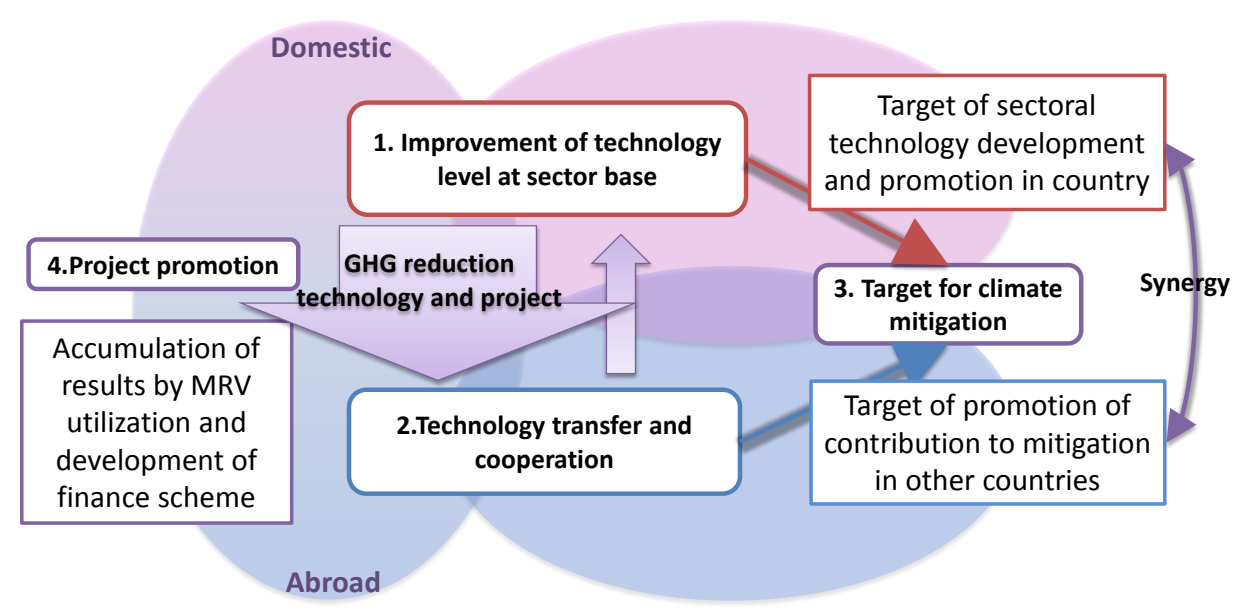

Figure2. Four pillars of Integrated Contribution Approach.

Moreover, "integrated” means (1) the integration of domestic and international levels of technology development and diffusion as well as target setting; (2) the integration of various schemes e.g. institutions and regulations and finance scheme.

Four pillars are summarized in detail as follows.

1. Improvement of technology level at sector base (Technology R \& D)

- Use of sectoral indicators as targets,

- Raising the levels of domestic R \& D and leading to technology innovation of energy efficient and environment technology, which contribute to improve world level technology,

- Applying experiences and extensive development of operation of domestic legal system and the constructed regulatory framework.

2. Technology transfer and cooperation (Technology diffusion)

- Using innovative and high-level of technology for global GHG reduction,

- Expanding application of technology which were already penetrated in a country but not fully diffused in other countries,

- Promoting introduction and diffusion of technology based on the needs and technological capability and maintaining environment aiming at the sustainable technical use,

- Developing new global market related to technology.

3. Target for climate mitigation (Technology target setting)

- Sectoral targeting the degree of improvement of technology,

- Counting mitigation contribution of technology transfer and cooperation, not only by JCM (Joint Crediting Mechanism) but also by ODA and private financing by grasping quantitatively mitigation efforts,

- In short term, reflecting to existing commitment framework such as INDC (Intended Nationally Determined Contributions),

- In medium and long term perspectives, regardless of the UNFCCC framework, incorporating into global climate mitigation goal.

4. Project promotion (Environment surrounding technology)

- Accumulating knowledge/experiences of domestic and international global mitigation performance using arranged MRV methodology and applying them to Project Promotion,

- Encouraging the finance scheme using MRV and integration of plural schemes.

For example, GHG reduction efforts, such as emission targets for energy-intensive industries, power generation efficiency, vehicle fuel consumption, household appliance performance, and insulation efficiency are accumulated and the results are disseminated both inside and outside the country. The institutional framework already in place and the experience gained through attempts to enforce existing laws and regulations can be applied to reduce the barriers for setting targets on the implementation of GHG reduction actions. Employing institution-based methodologies such as the EU directive on the energy efficiency and benchmark-based system, the US labelling system, or the Top Runner Program in Japan, it is possible to set mitigation targets to raise high 
technical capabilities within a given year while also performing a technical proof evaluation on the level of GHG reductions/energy efficiency through independent technical verification. In addition, it is possible to estimate the effect of reducing a given sector's emissions as a whole by calculation using the percentage of $\mathrm{CO}_{2} \mathrm{re}-$ duction and possible detailed reductions in each sector. There are also various systems available to fulfil monitoring and reporting requirements of energy saving.

Here, an Integrated Contribution Approach unifying the numerical targets and the reduction action targets is proposed as a core concept for the future mitigation framework. This approach can raise the value of high-level reduction actions such as improvements in energy efficiency, in conjunction with presenting a national GHG reduction target. It enables flexibility in response to commitments and review requirements that may be contained in a future UNFCCC. As described above, such target setting and implementation of reduction actions are consistent with domestic and regional legal enforcement. The further development of high-standard environmental and energy-saving technology is very beneficial to the broader evolution of science and technology as well. In addition, it is possible that high-level technology development will advance the state of the art overall; that is, as diffusion proceeds in other countries through technology cooperation and transfer, further GHG reduction can be expected, contributing to the mitigation of global climate change.

\subsection{The Effective Use of Advanced Technology}

In general, the level of mitigation technology in developed countries is higher than that of developing countries because the diffusion of those high-level technologies is insufficient, even if a state-of-the-art technology exists globally. In developing countries, it is very important to apply available advanced technology to improve GHG emission control. Furthermore, it is desirable that efforts to reduce GHG emissions be recognized as "a legitimate effort" by the entity implementing the reductions.

For example, in a paper published by the present authors [30] and cited in the IPCC's Fourth Assessment Report in 2007 [31], looking at the potential for GHG reduction by applying energy-saving technology in the steel industry (Figure 3) in the IPCC B2 scenario, a possible reduction of 210 million tons of $\mathrm{CO}_{2}$ globally by 2030 was estimated through the use of best available technology. Reduction potential is high in China, India, and other Asian countries including Non-Annex I East Asia, as well as the former Soviet Union and Europe, all of which have considerable steel production. On the other hand, these techniques are widely used already, and the steel industry and other heavy industries are able to provide such technologies to other countries. To realize this worldwide reduction, it is important to introduce these technologies in areas of low diffusion rate. It is desirable that introduction and deployment of technology are promoted while considering the needs and technical capacities of the host country; thus, appropriate matching of technology is important.

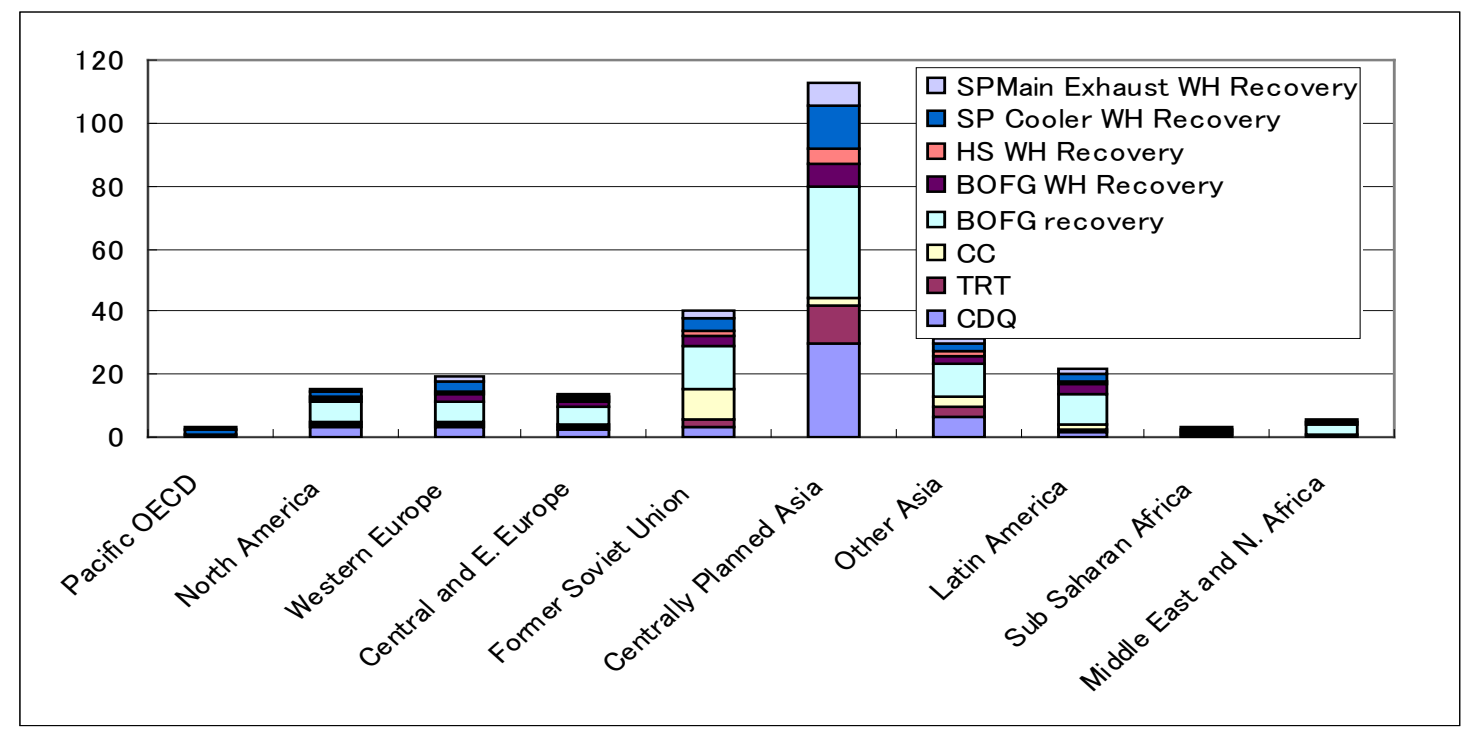

Figure 3. Evaluation of the potential for GHG reduction through the application of energy-saving technology in the steel industry [30]. 


\subsection{The Importance of Gaining a Quantitative Understanding of the Cost of Technical Development Assistance and the Value of Technology Transfer (Japanese Case)}

In the period from October 2009 through December 2012, Japan provided \$17.6 billion in support for GHG reduction activities to developing countries. This amount comprised approximately \$3.6 billion in public funds such as Official Development Assistance (ODA) and approximately \$14 billion from private-sector sources such as the Japan Bank for International Cooperation (JBIC).

Although precise data are not available, approximately $50 \%-60 \%$ of this assistance may be related to mitigation measures. The Japanese Minister of the Environment, Nobuteru Ishihara, proposed at COP19 "further technology innovation, application to the world of the Japanese low carbon technology, support 1600 billion yen (approximately 16 billion dollars) to the developing country for three years from 2013 through 2015”. This was a strong endorsement of roughly doubling Japan's level of investment in the implementation of mitigation measures in developing countries.

For a sponsoring country, it is desirable to make this expenditure a meaningful "expense" or "investment" as a practical contribution for preventing global warming. Important points here are the availability of information on the contribution to GHG emission reduction, and quantification of the amount of reduction achieved in these foreign countries. The estimates should be quantitative and should specify where (what region or country), when and how (by what transfer of technology) the reductions will be attained. Furthermore, it is desirable to perform a correlation between the amount of GHG reduction and the amount of the contribution to clarify cost-effectiveness. It is necessary to represent the real overseas contribution. In the case of Japan, overseas investment schemes available to support global warming mitigation technology include public ODA and two private-sector financing options: the Japan International Cooperation Agency (JICA), or Global Action for Reconciling Economic Growth and Environmental Preservation (GREEN) by the JBIC. To assess the track record of mitigation attained by these investments, it is necessary to compile contributions and GHG reductions in a database and to analyze the data from a cost-effectiveness perspective to the extent possible. It is also necessary to gain an understanding of the cross-national technology cooperation and assistance schemes implemented by public authorities that do not appear in the list of ODA contributions, and these should be reflected in the database as well, along with their results. ${ }^{1}$ If possible, a mechanism to collect information on private-sector technology assistance to developing countries is also desirable.

In addition, we should focus on the purpose of each contribution, not just its origin. The purposes of technology cooperation related to climate mitigation are diverse, encompassing local environmental measures such as air pollution, forest and ecological protection, and regional sustainable development. In some cases, it is unclear whether reducing global warming is the primary purpose of the technology or a secondary aim; where global warming is a secondary concern, the climate mitigation impact is likely to be underestimated. In the process of database compilation, it is important to clarify these purposes so as not to overlook a portion of the total contribution made toward climate mitigation.

Although this is not a type of technology transfer itself, with regard to Nationally Appropriate Mitigation Actions (NAMAs) there is international cooperation on the development and maintenance of laws and regulations in connection with technology such as contributing to the formulation of various policies (e.g., energy conservation standards) in a developing country. In comparison with the mitigation actions based on technology, understanding the results and quantitative effects of the diffusion of these regulations is more difficult. However, enabling the system to compile and analyze this information is also desirable.

\subsection{Problems with Conservative Baseline Setting for Counting GHG Reduction in Existing Crediting Mechanism}

Currently, for the private sector, incentives to invest in sharing climate change mitigation technology with other countries are low. Although CDM and Joint Implementation (JI) were designed as schemes to promote mitigation activities in other countries, project development has been limited by the constraints of additionality.

The CDM/JI Executive Board spent considerable time reviewing this issue. Figure 4 shows the percentages of number of projects and credit value of CDM projects by type for the year 2012 summarized from UNEP

\footnotetext{
${ }^{1}$ For example, there is an overseas technical cooperation effort within the Ministry of Education, Culture, Sports, Science and Technology (MEXT) called SATREPS (Science and Technology Research Partnership for Sustainable Development). MEXT contributed research and development funds to match the ODA provided to developing countries. Contributions from MEXT were not included in the ODA amount.
} 


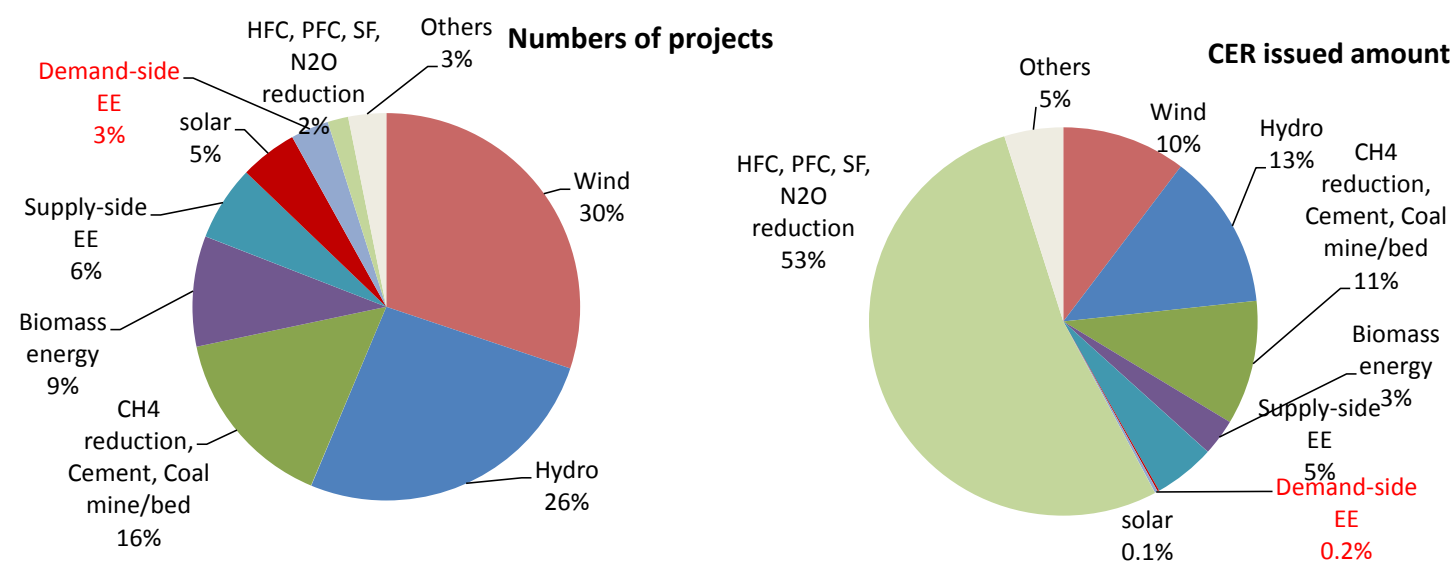

Figure 4. Percentages of number of projects and CER amount of CDM projects.

published data [32]. Most mitigation efforts were dedicated to non- $\mathrm{CO}_{2}$ reduction and renewable projects because of additionality; projects related to demand-side energy saving represented only $3 \%$ of the total number of projects, and $0.2 \%$ of the total certified emission reduction (CER) value. Moreover, ascredits generated would be suppressed by setting the baseline conservatively, the profits by CDM enforcement becameless on the project implementation side. Such CDM was ineffective in producing significant GHG reduction.

In addition, Karakosta et al. [22] indicates that these past CDM projects "concentrates on single projects mostly in isolation of the host country's national and technology context" and "does not foster the supporting systems needed to enhance adoption of new technology, ..." Furthermore, Flamos and Begg [33] raised as problems that the access to local market network was less and few assessment of energy service, market, policy and supporting service tailored to the situations in each host country.

Under these circumstances, within the UNFCCC, consideration of new and more flexible mechanisms began since COP16 [34] and "views on matters relating to the establishment of one or more market-based mechanisms to enhance the cost-effectiveness of, and to promote, mitigation actions" were submitted and proposed to the Ad Hoc Working Group on Long-term Cooperative Action under the Convention (AWG-LCA) by 19 countries as of February 2011 [35]. Among them, Japan has proposed an approach called the Joint Crediting Mechanism (JCM). This scheme is based on agreements between developing and developed countries to promote climate change mitigation and according to the decision at UNFCCC [36]. Within this JCM, which is considered the successor to the CDM, rules, guidelines, and methodologies can be formulated and revised between the two countries, and the credit is issued accordingly. Compared with the CDM, the JCM offers the advantages of shortening the procedure time significantly and flexibility to respond to actual countries' situations. On the other hand, partners are limited to parties to the Memorandum of Understanding (MoU) between two countries: Japan and the host country, and the availability of financial assistance and possibility of sales of credits are unclear at this moment, so that it has not been possible to increase the investment momentum on a large scale.

Moreover, a Japanese government publication has specified, "Using conservative default values in parameters to calculate project emissions instead of measuring actual values will lead calculated project emissions larger than actual project emissions [37]". In practice, indeed, when a certain technology is introduced, rather than business as usual $(\mathrm{BaU})$ as was assumed originally, it is expected that the $\mathrm{BaU}$ emissions will decline whenever technology is introduced. However, estimates will be influenced by how the future is projected—for example, in the case of power generation facilities, what happens with other power supply sources, how electricity demand increases or decreases, and what policies are adopted with regard to energy security. In such a situation, setting baseline values conservatively without a scientific basis could unnecessarily inhibit investment.

The Institute of Energy Economics, Japan reported the following interesting estimation [38]. In the case of introducing supercritical and ultra-supercritical power generation systems in Indonesia, for the calculation of amount $\mathrm{CO}_{2}$ reduction, there were seven possible ways to calculate the baseline:

(1) Option 1 of ACM0013²: the plant having the greatest thermal efficiency by the fuel and technology in

\footnotetext{
${ }^{2} \mathrm{ACM} 0013$ is a baseline setting methodology for CDM. The UNFCCC defined it as a "consolidated baseline and monitoring methodology for new grid connected fossil fuel fired power plants using a less GHG intensive technology" (see the UNFCCC website). http://cdm.unfccc.int/methodologies/DB/7E9VKG4RTU85IJ6HYJ3JTNLDHFDT2R
} 
which introduction is expected most in the area concerned,

(2) Option 2 of ACM0013: average of top 15\% plants in efficiency among the sample group, as narrowed down under the conditions required by ACM0013,

(3) Average of the five newest power plants, according to start of operation (300 MW to $500 \mathrm{MW}$ ),

(4) Average of the newest power plants, according to start of operation, up to the equivalent to $20 \%$ of the total power production in the area concerned,

(5) Average of all power plants (JAMALI grid ${ }^{3}$ ),

(6) J-MRV 004: average of all power plants in the area concerned,

(7) J-MRV 004: average of all power plants using the same fuel (in this case, coal) in the area concerned.

Table 1 shows the calculated $\mathrm{CO}_{2}$ emissions reduction amount in the case of introducing the new technology in the area concerned. In cases based on the CDM scheme ((1) and (2)) and those using intensity averages of plants with higher thermal efficiency ((3) and (4)), as compared to cases using the average of all plants ((5) through (7)), emission reduction estimates were smaller. In addition, the baseline power generation efficiency increases at existing power plants as newer power generation facilities are introduced, with the result that $\mathrm{CO}_{2}$ emission reductions calculated by using the difference between baseline emissions and the new technology become close to zero. For example, in case (1), when it is judged that highly efficient power plants have become the majority, $\mathrm{CO}_{2}$ reduction becomes zero; this result could occur even sooner in cases (2), (3), and (4). This means that no reduction can be counted even if the technology is introduced, negatively impacting operators' incentives to implement new technology. As a result, a situation arises in which additional plants do not follow the lead of the first few plants to implement new technology because the motivation for doing so has been lost. It is necessary to successively introduce multiple projects to promote the penetration and application of high-level technology for climate mitigation.

The problems inherent in such conservative forms of baseline establishment should be recognized, and it is necessary to consider action to address this problem. Quantitatively evaluating the GHG emission reduction amount achieved by the use of low-carbon technology, not only by JCM but in various technical cooperation and transfer schemes, MRV methodology should be carefully discussed. Even though a certain calculation method is set up originally, the accumulation of information will be desirable to implement another calculation method using primary source data.

\section{The Need for a New Financing Mechanism for Overseas Technology Cooperation and Transfer}

\subsection{Efficient Access to Financing of Technology Transfer and Investment Projects}

Table 2 indicates estimated GHG mitigation potentials in industry in 2030 for different cost categories [39]. Although some options can be executed at a cost less than $\$ 20 \mathrm{US} / \mathrm{tCO}_{2}$-eq, there are many options that cost more than this amount. To ensure effective implementation, it is important that the financial risk is low.

Table 1. Estimation results of $\mathrm{CO}_{2}$ emission reductions by the successive introduction of supercritical power generation systems (in the case of using lignite as fuel) (in $10000 \mathrm{t} \mathrm{CO}_{2} / \mathrm{y}$ ).

\begin{tabular}{|c|c|c|c|c|c|c|c|}
\hline & $1^{\text {st }}$ & $2^{\text {nd }}$ & $3^{\text {rd }}$ & $4^{\text {th }}$ & $5^{\text {th }}$ & $6^{\text {th }}$ & $7^{\text {th }}$ \\
\hline (1) Option 1 of ACM0013 & 57 & 57 & 57 & 0 & -- & -- & -- \\
\hline (2) Option 2 of ACM0013 & 58 & 24 & 0 & -- & -- & -- & -- \\
\hline (3) Average of 5 newer power plants & 71 & 45 & 31 & 19 & 8 & 0 & -- \\
\hline $\begin{array}{l}\text { (4) Average of newer power plants up to } 20 \% \text { of the total power } \\
\text { production }\end{array}$ & 83 & 56 & 25 & 0 & -- & -- & -- \\
\hline (5) Average of all power plant (JAMALI grid) & 173 & 154 & 139 & 126 & 115 & 107 & 99 \\
\hline (6) J-MRV 004: average of all power plants & 43 & \multicolumn{6}{|c|}{ Based on the government published value } \\
\hline (7) J-MRV 004: average of all power plants using the same fuel & 173 & 154 & 139 & 126 & 115 & 107 & 99 \\
\hline
\end{tabular}

Source: [38].

${ }^{3}$ The electricity grid of Java, Madura and Bali. 
Table 2. Estimated economic potentials for GHG mitigation in industry in 2030 for different cost categories using the SRES B2 baseline.

\begin{tabular}{|c|c|c|c|c|c|c|c|}
\hline \multirow{2}{*}{ Mitigation option } & \multirow{2}{*}{ Region } & \multicolumn{2}{|c|}{$\begin{array}{l}\text { Economic potential } \\
\left(\mathrm{MtCO}_{2} \text {-eq }\right)\end{array}$} & \multicolumn{4}{|c|}{$\begin{array}{l}\text { Economic potential }\left(\mathrm{MtCO}_{2} \text {-eq) in different cost }\right. \\
\text { categories }\left(\mathrm{US} \$ \mathrm{tCO}_{2} \text {-eq) }\right.\end{array}$} \\
\hline & & Low & High & $<0$ & $0-20$ & $20-50$ & $50-100$ \\
\hline \multirow{3}{*}{ Electicity savings } & OECD & \multicolumn{2}{|c|}{300} & & 70 & 70 & 150 \\
\hline & EIT & \multicolumn{2}{|c|}{80} & & 20 & 20 & 40 \\
\hline & Non-OECD/EIT & \multicolumn{2}{|c|}{450} & & 100 & 100 & 250 \\
\hline \multirow{3}{*}{$\begin{array}{l}\text { Other savings, } \\
\text { including non- } \mathrm{CO}_{2} \\
\text { GHG }\end{array}$} & OECD & 350 & 900 & & 300 & 250 & 50 \\
\hline & EIT & 200 & 450 & & 80 & 250 & 20 \\
\hline & Non-OECD/EIT & 1200 & 3300 & & 500 & 1700 & 80 \\
\hline \multirow{4}{*}{ Total } & OECD & 600 & 1200 & & 350 & 350 & 200 \\
\hline & EIT & 250 & 550 & & 100 & 250 & 60 \\
\hline & Non-OECD/EIT & 1600 & 3800 & & 600 & 1800 & 300 \\
\hline & Global & 2500 & 5500 & & 1100 & 2400 & 550 \\
\hline
\end{tabular}

Source: [39].

When companies and organizations invest in climate change mitigation and energy-saving technology applications in other countries, it should be made clear what types of investment processes are best for the country and the company. When there is a possibility of multiple funding sources as in Japan, coordination of procedures can maximize efficiency.

Figure 5 illustrates the screening flow when using the various loan sources for technology transfer and investment projects like those envisioned in this paper. This flow is for the project developer. Using the rate of return calculated before investment, one can readily recommend which loan source the developer should use. The financial source is determined by the financial internal rate of return (FIRR) of a planning phase. Applying this information simplifies the flow of the loan process for the project developer and thereby reduces transaction costs. This improvement in procedural efficiency also causes financial markets to become more active. A comparably simple approach can be constructed from the host country's perspective. For new institutions seeking to provide financing for climate change mitigation measures, the barriers to entry can be made low.

Again, it is important that the amount of reduction of greenhouse gases is actually recorded numerically, and that the contribution resulting from the technology transfer is clarified. The JBIC loan, for example, requires the use of a prescribed MRV method as a condition of applying lower interest rates. In JICA, although MRV is not used in decisions on loan implementation, it is executed to clarify the reduction effect. For a financing institution, the use of MRV enables effective project monitoring and increases transparency regarding both mitigation and economic effects, which in turn leads to better risk management and promotion.

\subsection{Selection of Loans Based on the Rate of Return}

A scheme that can realize a project with as low rate of return as possible is proposed. In Figure 4, the JICA ODA loans, JICA private-sector investment financing, JBIC and other private lending are listed. In general, the highest interest rate comes from private lending, followed by JBIC, and then by JICA private-sector investment finance. The JICA ODA loan rate is much lower than others; for example, a rate of $0.01 \%$ is applied to environmental and climate projects in the least developed countries as of April 2014 [40]. For project developers, a lower interest rate is obviously desirable. To receive low interest rates, projects should not only demonstrate economic efficiency but also meet other conditions: they should use prescribed MRV and should have high levels of environmental integrity, business feasibility and development impact. In the case of very low-interest JICA ODA loans, the situation in the host country is another important consideration. In the host country, the government takes the initiative and makes a request in line with the country's development strategy. Close consultation between the host country and JICA is required. For example, even forest-related projects, which are generally viewed as unprofitable, can currently get low-interest JICA ODA loans. Thus, at present, ODA loans can be applied to projects with low profitability. In cases that involve the promotion and expansion of technology 


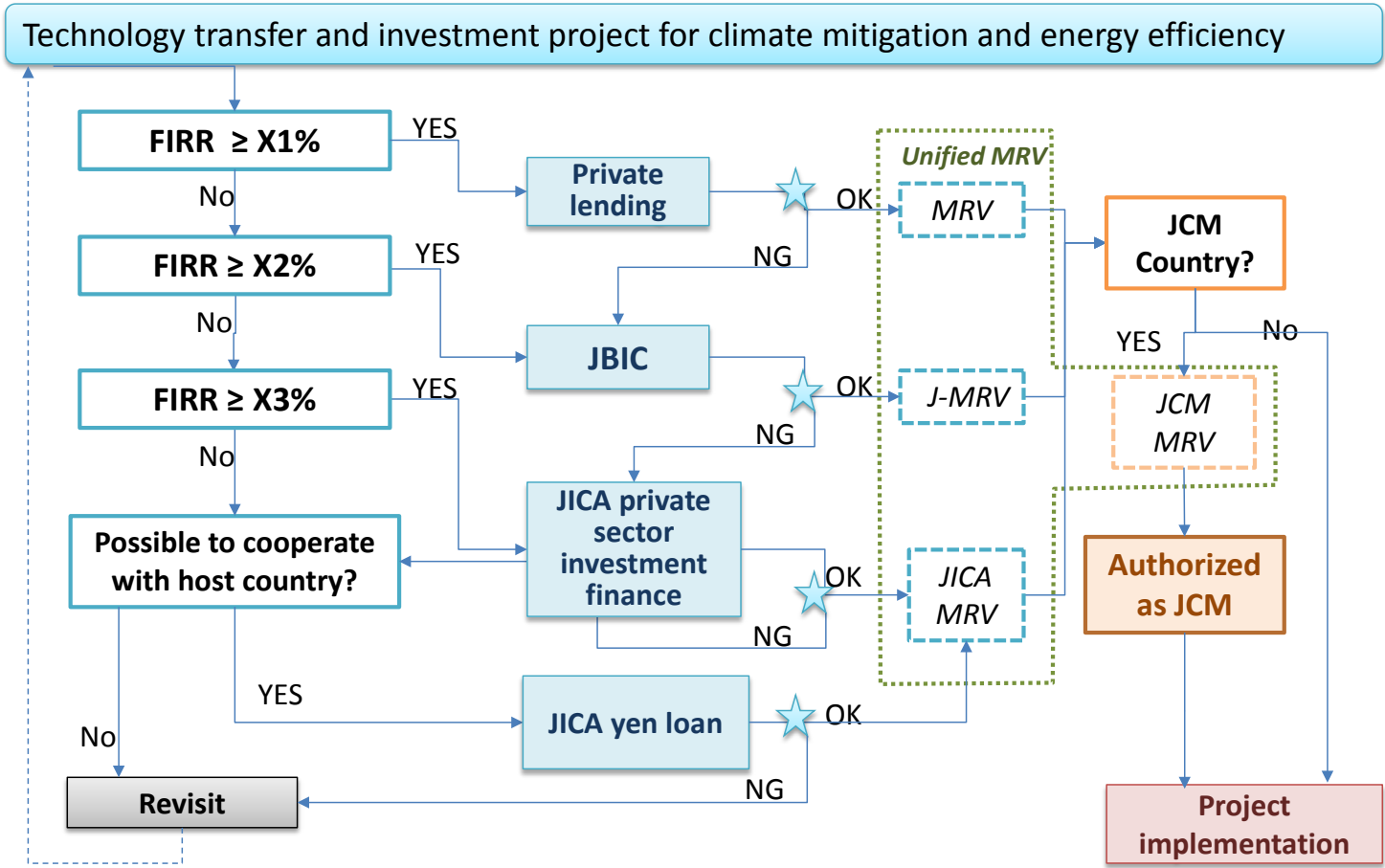

FIRR: Financial Internal Rate of Return

$\hbar$ Loan judgment is examined not only with the rate of return but with a synthetic debt repayment possibility, and the standard varies according to organization.

Figure 5. Proposed screening flow of loan applications for technology transfer and investment projects in Japan.

transfer, however, funding should not be limited to ODA loans; rather, it is important to broaden the range of financial assistance. For instance, a system is needed by which the lower interest rate can be applied when an evaluation index such as economic internal rate of return (EIRR) exceeds a specified value.

By way of illustration, Table 3 summarizes the result of screenings as applied in a simple manner to six climate mitigation technologies. FIRRs used for this trial were assumed as shown in Table 4. For example, for a rubber tree plantation project, screening results provided guidance enabling the project operators (i.e., the investor or host country) to focus on applying for a JICA ODA loan.

\subsection{Scheme Not Prioritizing "Generation of Credits"}

JCM is the scheme that the Japanese government is promoting as an international framework. When a country that has concluded an MoU is the host country, a project would be advanced under the JCM scheme and the generated credit would be authenticated internationally. However, the number of MoU countries is limited at this time, thus restricting Japan's overall potential to contribute toward GHG reduction. Assuming that credit generation is indispensable, there is a possibility that issues of additionality will be rekindled, and concluding an $\mathrm{MoU}$ entails a huge transaction cost and a time-consuming process. These factors all discourage efforts to achieve substantial GHG reductions.

There are many opportunities for GHG reduction that cannot be overseen by a UNFCCC-approved institution such as JCM. For example, let us consider the deployment of photovoltaic (PV) solar cells in developing countries. Hoogwijkderived a PV applicable area based on land use information regarding the theoretical potential of solar energy reaching various continents and areas, and then estimated the technical potential of solar energy for a centralized, grid-connected system [44] [45]. From the solar energy potential, we calculated the technical potential of PV generation in each area for 2013 and 2020 (prospectively) using solar cell module efficiency data published by LCS/JST [46], assuming no significant change in land use in 2020 (see Table 5). The latest IEA data show electricity production as 9 PWh in 2012 for developing countries in these areas [47]. Technical potential was estimated at 35 times actual generation amounts, indicating huge possibilities for technology-based $\mathrm{CO}_{2}$ 
Table 3. Results of trial screenings of six climate mitigation technologies.

\begin{tabular}{|c|c|c|c|c|c|}
\hline Project & $\begin{array}{l}\text { Rubber tree } \\
\text { plantation }\end{array}$ & $\begin{array}{l}\text { Electric efficiency } \\
\text { improvement at } \\
\text { vehicle factory }\end{array}$ & $\begin{array}{c}\text { Waste heat } \\
\text { recovery } \\
\text { generation at } \\
\text { cement industry }\end{array}$ & $\begin{array}{l}\text { Ultra-supercritical } \\
\text { coal-fired power } \\
\text { generation }\end{array}$ & $\begin{array}{l}\text { Solar power } \\
\text { generation plant }\end{array}$ \\
\hline Reference & [41] & [41] & [41] & [42] & [43] \\
\hline Country & Cambodia & China & China & Philippines & India \\
\hline Technology area & Afforestation & Energy efficiency & $\begin{array}{l}\text { Waste heat } \\
\text { recovery }\end{array}$ & $\begin{array}{l}\text { High efficiency power } \\
\text { generation }\end{array}$ & Renewables \\
\hline $\mathbf{I R R}^{(1)}$ & $5.1 \%$ (35 yrs) & 8\% (10 yrs) & $6.5 \%$ (10 yrs) & $23.1 \%$ & $10.84 \%$ (7 yrs) \\
\hline Benchmark IRR ${ }^{(2)}$ & $15 \%$ & $11 \%$ & $11 \%$ & $11 \%$ & $14 \%$ \\
\hline $\begin{array}{c}C f: \text { rate of sovereign } \\
\text { bond }\end{array}$ & (Not issued) & $4.1 \%$ & $4.1 \%$ & $3.9 \%$ & $8.7 \%$ \\
\hline Screening result & $\begin{array}{l}\text { JICA ODA } \\
\text { loan }\end{array}$ & $\begin{array}{c}\text { JBIC, JICA } \\
\text { private sector } \\
\text { investment finance }\end{array}$ & JICA ODA loan & Private lending & $\begin{array}{c}\text { JBIC, JICA } \\
\text { private sector } \\
\text { investment finance }\end{array}$ \\
\hline
\end{tabular}

(1) The significant figures of IRR are according to the original source. (2) Benchmark IRR in this table was set with reference to lending rates for companies by private banks in the country concerned.

Table 4. Assumed FIRR used for trial screening.

\begin{tabular}{ll} 
& \\
\hline$\geq$ Benchmark IRR (corresponding to X1 of Figure 4$)$ & Private lending \\
$\geq$ Benchmark IRR $-5^{*},<$ Benchmark IRR $(X 2$ and X3) & JBIC, JICA private sector investment finance \\
$<$ Benchmark IRR $-5^{*}(\mathrm{X} 2$ and X3) & JICA ODA loan \\
\hline
\end{tabular}

*This value is assumed for convenience in this paper, and is unrelated to the investment decision of each financial institution. These numbers would need to be further examined.

reductions in the developing world associated with various business opportunities. Furthermore, the realization of the level of efficiency assumed here for future PV requires continual R \& D efforts, thereby calling for further technology innovations.

In order to deal with these technical potentials, it is important to develop mechanisms to promote private investment incentives and to utilize various business opportunities in the economic development of a developing country. This could reduce GHG emissions significantly and clarify the level of country-level contributions required. The sponsoring government, project developer, local host and various financial institutions are connected seamlessly and share roles, and it is vital to demonstrate their overall power in the project. Thereafter, it is necessary to quantify the contribution and confirm the amount of reduction achieved by a project numerically through MRV.

\section{Conclusions and Policy Implications}

With regard to the future climate mitigation framework, we have proposed an Integrated Contribution Approach, which can be effective in supporting GHG reduction at both the national and international levels, using transfer and promotion of energy and environmental technologies. This approach can achieve the following goals:

- Promoting further R \& D and innovation of high-level energy efficiency and low-carbon technology.

- Supporting industry and driving its further development by focusing on technical capabilities.

- Utilizing the experience gained from the established framework and enforcement of existing laws and regulations in project implementation.

- Clarifying the objectives of mitigation actions and managing the mitigation achievement process.

- Contributing to technology cooperation and transfer for global mitigation in an efficient way, and demonstrating the extent of contribution quantitatively.

Even if numerical targets for GHG reduction are set for a country, it is possible to assist achievement of the desired reduction in practice by facilitating technology transfer and implementation projects.

In order to embody and realize this approach, beyond the UN framework, it is necessary to identify a country's technical area of interest related to energy efficiency and GHG reduction, clarify the technological strategy, 
Table 5. Technical potential of generation by photovoltaic solar cells.

\begin{tabular}{ccccc}
\hline & $\begin{array}{c}\text { Theoretical potential of } \\
\text { solar energy reaching } \\
\text { the area (EWh/y) }\end{array}$ & $\begin{array}{c}\text { Technical potential of } \\
\text { solar energy for } \\
\text { applicable area (PWh/y) }\end{array}$ & $\begin{array}{c}\text { 2013 PV generation } \\
\text { technical potential } \\
\text { (PWh/y) }\end{array}$ & $\begin{array}{c}\text { 2020 PV generation } \\
\text { technical potential } \\
\text { (PWh/y) }\end{array}$ \\
\hline $\begin{array}{c}\text { Central and South } \\
\text { America }\end{array}$ & 28 & 28 & 35 & 48 \\
Africa & 49 & 150 & 186 & 257 \\
Middle East & 10 & 37 & 46 & 63 \\
Asia (excl. Japan) & 30 & 54 & 67 & 93 \\
Total & 117 & 269 & 333 & 461 \\
\hline
\end{tabular}

Note: For PV generation, module efficiencies were used: 13\% for 2013 and 18\% for 2020 by copper indium gallium selenide (CIGS); new tandem-type technology is assumed for 2030. Costs including module and BOS systems were also estimated: 163 JPY/W for 2013 and 97 JPY/W for $2020[46]$.

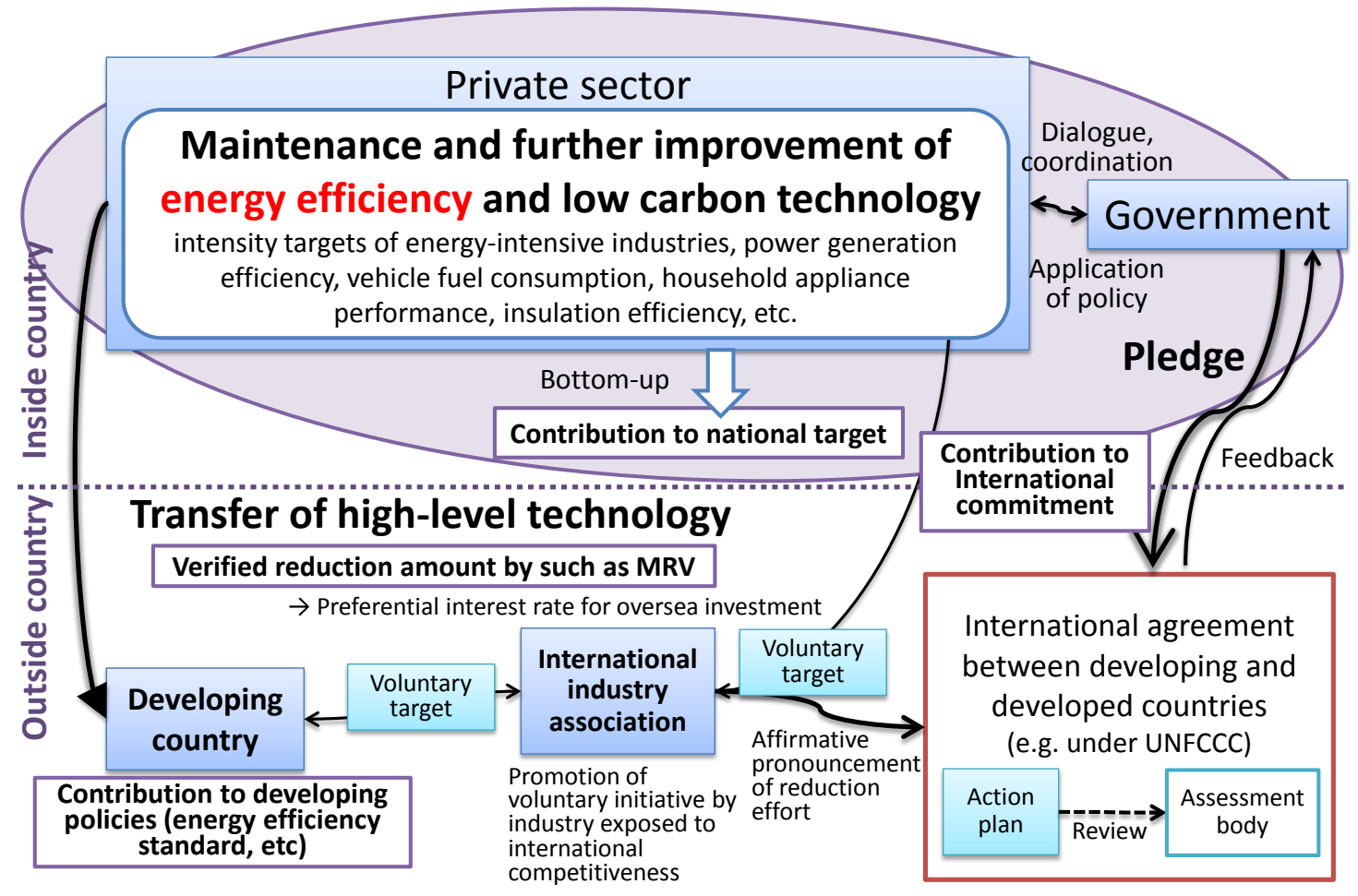

Figure 6. A detailed representation of the national and international schemes proposed in this paper.

set the target by aggregating reduction efforts by area/sector, and construct a path to specify the reduction effect. The supporting environment for the development, diffusion and promotion of technology should be improved, and the necessary regulations and laws to enable technical cooperation should also be in place. In addition, it is necessary to create a database that will accumulate, analyze and publish data regarding domestic technical contributions and diffusion systems, overseas technology transfer and cooperation on energy saving and GHG reductions. Furthermore, it is important to create mechanisms by which the private sector can benefit from financing for mitigation activities in foreign countries. Expanding the voluntary activities of the private sector, the potential for achieving technology cooperation and transfer can be realized, resulting in greater global GHG reductions along with improved cash flow for a broad range of participating entities. Figure 6 summarizes and extends the scheme proposed in this paper. Our key challenge for global climate mitigation is what we will do in the next decades both within and beyond the UNFCCC regime.

In this Integrated Contribution Approach, we have focused on the coordination between technical efforts and the energy-efficiency technology policies being developed in many countries of the world, as a core component of the proposed scheme. For example, the approach encompasses energy-saving equipment efficiency and 


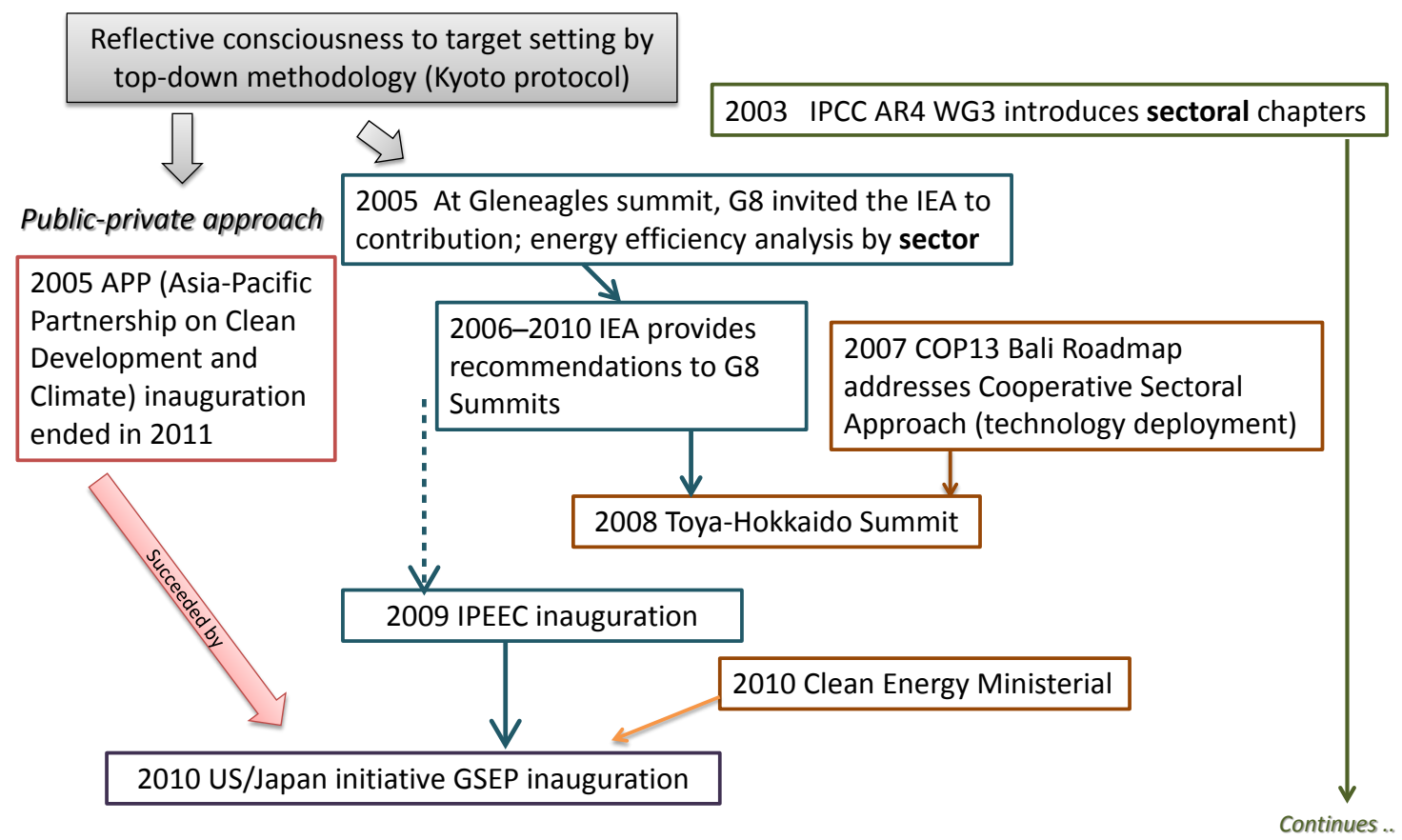

Figure 7. The transition to an international sectoral approach.

energy saving in the manufacturing process. To achieve these improvements, support for programs at the research and development stage, policy development, researcher training and education all become important. We need a scheme that can combat global warming on a global scale by taking full advantage of private-sector resources, fostering and making use of technology, and stimulating and promoting technical innovation.

\section{Appendix: Sectoral Approach}

The concept of a sectoral approach has several meanings depending on who is using the term. Generally, the meanings can be classified in the following four ways:

- Calculation methodology of potential

$>\mathrm{CO}_{2}$ emission reduction amount by bottom-up calculation,

$>$ Benchmarking, sectoral energy efficiency standard.

- Framework of initiatives and actions

$>$ Cooperative sectoral approach (APP, GSEP, etc.).

- Background thinking and the method of numerical target setting

$>$ Numerical targets for same sectors; sectoral CDM.

- A key word describing a specific negotiation stance

Figure 7 traces the process of transition to sectoral approaches within prior global frameworks. The word sectoral has often been used to express a bottom-up approach in contradistinction to top-down approaches such as country-level targets. Even now, for example, in such frameworks as the International Partnership for Energy Efficiency Cooperation (IPEEC) and Global Superior Energy Performance Partnership (GSEP), concepts of sectoral approaches remain alive.

\section{Acknowledgements}

For the preparation of this material, the authors highly appreciate the contributions of the Japanese government members, Ministry of Economy, Trade and Industry, Ministry of Environment, Ministry of Education, Culture, Sports, Science and Technology, and Ministry of Land, Infrastructure, Transport and Tourism. We would also like to thank the JICA and JBIC experts for providing their valuable insights through a very fruitful discussion on this issue. Also, the discussion with Mr. James Connaughton (C3 Energy) was quite encouraging and is highly appreciated. The authors also would like to thank Enago (http://www.enago.jp) for the English language review. There is no involvement of any funding sources for this research. 


\section{References}

[1] IPCC (Intergovernmental Panel on Climate Change) (2014) Technical Summary, Climate Change 2014: Mitigation of Climate Change. Working Group III, the Fifth Assessment Report, 26-28.

[2] IISD (International Institute for Sustainable Development) (2013) Earth Negotiation Bulletin, ADP2 Final. http://www.iisd.ca/download/pdf/enb12568e.pdf

[3] MOE Japan (Ministry of Environment) (2013) Press Release on ADP2. http://www.env.go.jp/press/press.php?serial=16622

[4] UNFCCC (2014) Report of the Conference of the Parties on Its Nineteenth Session, Held in Warsaw from 11 to 23 November 2013, Addendum, Part Two: Action Taken by the Conference of the Parties at Its Nineteenth Session, FCCC/CP/2013/10/Add.1.

[5] UNFCCC (2015) Paris Agreement. http://unfccc.int/files/meetings/paris_nov_2015/application/pdf/paris_agreement_english_.pdf

[6] IPCC (2014) Summary for Policy Makers, Climate Change 2014: Mitigation of Climate Change. Working Group III, the Fifth Assessment Report, 29.

[7] Meyer, A. (1998) The Kyoto Protocol and the Emergence of "Contraction and Convergence" as a Framework for and International Political Solution to Greenhouse Gas Emissions Abatement, Man-Made Climate Change-Economic Aspects and Policy Options. 291-345.

[8] Hoehne, N., den Elzen, M. and Weiss, M. (2006) Common but Differentiated Convergence (CDC): A New Conceptual Approach to Long-Term Climate Policy. Climate Policy, 6, 181-199. http://dx.doi.org/10.1080/14693062.2006.9685594

[9] Den Elzen, M., Berk, M., Lucas, P., Criqui, P. and Kitous, A. (2006) Multi-Stage: A Rule Based Evolution of Future Commitments under the Climate Change Convention. International Environmental Agreements: Politics, Law and Economics, 6, 1-28. http://dx.doi.org/10.1007/s10784-004-5645-3

[10] Den Elzen, M., Hoehne, N. and Moltmann, S. (2008) The Triptych Approach Revisited: A Staged Sectoral Approach for Climate Mitigation. Energy Policy, 36, 1107-1127. http://dx.doi.org/10.1016/j.enpol.2007.11.026

[11] Groenenberg, H., Blok, K. and van der Sluijs, J.P. (2004) Global Triptych: A Bottom-Up Approach for the Differentiation of Commitments under the Climate Convention. Climate Policy, 4, 153-175.

[12] Jansen, J.C., Battjes, J.J., Sijm, J.P.M., Volkers, C.H. and Ybema, J.R. (2001) The Multi-Sector Convergence Approach: A Flexible Framework for Global Rules for National Greenhouse Gas Emissions Mitigation Targets. ECNC--01-007, CICERO WP 2001: 4, Energy Research Centre of the Netherlands and Center for International Climate and Environment Research, Oslo.

[13] Baron, R., Reinaud, J., Genasci, M. and Philibert, C. (2007) Sectoral Approaches to Greenhouse Gas Mitigation-Exploring Issues for Heavy Industry. IEA Information Paper, November 2007.

[14] Matsuhashi, R., Misumi, K. and Yoshida, Y. (2007) Comparative Analyses of Sector-Based Approaches and National Numerical Targets as Post-Kyoto Frameworks. ISEIS Publication Series Number P002, 5, 36-41.

[15] Matsuhashi, R., Mori, H., Misumi, K. and Yoshida, Y. (2008) Evaluation of Post-Kyoto Frameworks Focusing on Sector-Based Approaches and National Numerical Targets. Forum on Public Policy.

[16] UNFCCC (2014) ADP 2-4 Highlights Wednesday 12 March. https://unfccc.int/meetings/bonn_mar_2014/items/8128txt.php

[17] Tanaka, K. (2011) Review of Policies and Measures for Energy Efficiency in Industry Sector. Energy Policy, 39, 65326550. http://dx.doi.org/10.1016/j.enpol.2011.07.058

[18] Forsyth, T. (1998) Technology Transfer and the Climate Change Debate. Environment (Philadelphia), 40, 16-20. http://dx.doi.org/10.1080/00139159809605098

[19] Metz, B., Davidson, O., Martens, J.-W., Van Rooijen, S. and Van WieMcgrory, L., Eds. (2000) Methodological and Technological Issues in Technology Transfer. IPCC Cambridge University Press, Cambridge, 432.

[20] Martinot, E., Sinton, J. and Haddad, B. (1997) International Technology Transfer for Climate Change Mitigation and the Cases of Russia and China. Annual Review of Energy and the Environment, 22, 357-401. http://dx.doi.org/10.1146/annurev.energy.22.1.357

[21] Kathuria, V. (2002) Technology Transfer for GHG Reduction: A Framework with Application to India. Technological Forecasting \& Social Change, 89, 405-430. http://dx.doi.org/10.1016/S0040-1625(01)00137-8

[22] Karakosta, C., Doukas, H. and Psarras, J. (2010) Technology Transfer through Climate Change: Setting a Sustainable Energy Pattern. Renewable and Sustainable Energy Reviews, 14, 1546-1557.

http://dx.doi.org/10.1016/j.rser.2010.02.001 
[23] Ockwell, D., Haum, R., Mallett, A. and Watson, J. (2010) Intellectual Property Rights and Low Carbon Technology Transfer: Conflicting Discourses of Diffusion and Development. Global Environmental Change, 20, 729-738. http://dx.doi.org/10.1016/j.gloenvcha.2010.04.009

[24] Lema, A. and Lema, R. (2013) Technology Transfer in the Clean Development Mechanism: Insights from Wind Power. Global Environmental Change, 23, 301-313. http://dx.doi.org/10.1016/j.gloenvcha.2012.10.010

[25] Talaei, A., Ahadi, M. and Maghsoudy, S. (2014) Climate Friendly Technology Transfer in the Energy Sector: A Case Study of Iran. Energy Policy, 64, 349-363. http://dx.doi.org/10.1016/j.enpol.2013.09.050

[26] Kypreos, S. and Turton, H. (2011) Climate Change Scenarios and Technology Transfer Protocols. Energy Policy, 39, 844-853. http://dx.doi.org/10.1016/j.enpol.2010.11.003

[27] Chakravarty, S., Chikkautur, A., de Coninck, H., Pacela, S., Socolow, R. and Tavoni, M. (2009) Sharing Global $\mathrm{CO}_{2}$ Emission Reductions among One Billion High Emitters. Proceedings of the National Academy of Sciences of the United States of America, 106, 11884-11888. http://dx.doi.org/10.1073/pnas.0905232106

[28] Den Elzen, M., Hof, A. and Roelfsema, M. (2013) Analysing the Greenhouse Gas Emissions Reductions of the Mitigation Action Plans by Non-Annex I Countries by 2020. Energy Policy, 56, 633-643. http://dx.doi.org/10.1016/j.enpol.2013.01.035

[29] Roelfsema, M., den Elzen, M., Hoehne, N., Hof, A., Braun, N., Fekete, H., Bottcher, H., Brandsma, R. and Larkin, J. (2014) Are Major Economies on Track to Achieve Their Pledges for 2020? An Assessment of Domestic Climate and Energy Policies. Energy Policy, 67, 781-796. http://dx.doi.org/10.1016/j.enpol.2013.11.055

[30] Tanaka, K., Matsuhashi, R., Nishio, M., and Kudo, H. (2006) $\mathrm{CO}_{2}$ Reduction Potential by Energy Efficient Technology in Energy Intensive Industry. Industry Expert Review Meeting to the Fourth Assessment of Working Group 3 IPCC, Cape Town, 17-19 January 2006. http://eneken.ieej.or.jp/en/data/pdf/324.pdf

[31] IPCC (2007) Industry Chapter. In: Climate Change 2007: Mitigation, Contribution of Working Group III to the Fourth Assessment Report, Figure 7.1, 462.

[32] UNEP (2015) CDM Projects Grouped in Types. UNEP RISO Centre. http://cdmpipeline.org/cdm-projects-type.htm

[33] Flamos, A. and Begg, K. (2010) Technology Transfer Insights for New Climate Regime. Environment, Development and Sustainability, 12, 19-33. http://dx.doi.org/10.1007/s10668-008-9177-9

[34] UNFCCC (2010) FCCC/CP/2010/7/Add.1, Decision 1/CP. 16, Paragraph 87. http://unfccc.int/resource/docs/2010/cop16/eng/07a01.pdf

[35] UNFCCC (2011) Views on the Elaboration of Market-Based Mechanisms. Ad Hoc Working Group on Long-Term Cooperative Action under the Convention, 14th Session, Bangkok, 5-8 April 2011, and Bonn, 6-17 June 2011. http://unfccc.int/resource/docs/2011/awglca14/eng/misc02.pdf

[36] UNFCCC (2012) FCCC/CP/2012/8/Add. 1, Page 9, Paragraph 41.

[37] Government of Japan (2014) Recent Development of the Joint Crediting Mechanism (JCM). January 2014. http://www.env.go.jp/earth/ondanka/mechanism/bilateral/attach/jcm-bocm_trend1401_2.pdf

[38] IEEJ (Institute of Energy Economics, Japan) (2011) Heisei 22 nendo Chikyu Ondan kataisakugijutsunadosuishinjigyou "Indonesia niokerukoukouritsusekitankaryokuhatsudenshisetsudounyu no kanousei to sonokouka (In English: Global Warming Countermeasure Technology Dissemination Promotion FY2010, Feasibility Study on High Efficient coal Fired Power Generation Plant in Indonesia). Table 2.3.17.

[39] IPCC (2007) Industry Chapter, in Climate Change 2007: Mitigation. Contribution of Working Group III to the Fourth Assessment Report, Table 7.10, 477.

[40] JICA (Japan International Cooperation Agency) (2014) Terms and Conditions of Japanese ODA Loans. http://www.jica.go.jp/english/our_work/types_of_assistance/oda_loans/standard/2013.html

[41] GEC (Global Environment Centre Foundation) (2014) Reports of CDM/JI Feasibility Studies. http://www2.gec.jp/main.nsf/en/Activities-CDMJI FS Programme-List

[42] JST (Japan Science and Technology Agency) (2012) Report on Power Generation Technology Transfer- $\mathrm{CO}_{2} \mathrm{Mitiga}_{-}$ tion and Project Finance. March 2012.

[43] Green Clean Guide (2011) India’s First Solar PV Project Registered under the CDM. http://greencleanguide.com/2011/09/24/indias-first-solar-pv-cdm-project/

[44] Hoogwijk, M.M. (2004) On the Global and Regional Potential of Renewable Energy Sources. Universiteit Utrecht, Utrecht.

[45] Hoogwijk, M. and Graus, W. (2008) Global Potential of Renewable Energy Sources: A Literature Assessment. ECOFYS.

[46] LCS/JST (Center for Low Carbon Society Strategy/Japan Science and Technology Agency) (2014) PV Power Systems: 
Quantitative Technology Scenarios, and Science and Technology Roadmap Based on Elemental Technology Structure. Strategy for Technology Development, Proposal Paper for Policy Making and Governmental Action toward Low Carbon Societies, LCS/JST, 2014. 3. http://www.jst.go.jp/lcs/documents/publishes/item/fy2013-pp-02.pdf

[47] OECD/IEA (2014) World Energy Statistics. IEA Publishing, Modified by Tanaka, K., LCS/JST, Licence. http://www.iea.org/t\&c/termsandconditions/ 